\title{
Bile Duct Brushings in a Jaundiced Woman
}

\section{Alfred J Garcia ${ }^{1}$ and Jennifer M Smith ${ }^{2 *}$}

${ }^{1}$ Fellow in Cytopathology, Los Angeles County and University of Southern California, Los Angeles, USA

${ }^{2}$ Department of Pathology, Keck School of Medicine, University of Southern California, Los Angeles, USA

"Corresponding author: Jennifer Smith, Los Angeles County and University of Southern California, Med Ctr, Room CTA7A115, 1100 N. State Street, Los Angeles, CA 90033, USA, Tel: 323-409-1368; Fax: 323-441-8183; E-mail: smit338@usc.edu

Received date: Sep 26, 2015, Accepted date: Sep 29, 2015; Published date: Oct 01, 2015

Copyright: ( 2015 Garcia AJ, et al. This is an open-access article distributed under the terms of the Creative Commons Attribution License, which permits unrestricted use, distribution, and reproduction in any medium, provided the original author and source are credited.

\section{Description}

48 year old female with a history of choedocholithiasis who presented with recurrent abdominal pain and jaundice. Imaging/
ERCP revealed a high grade common bile duct stricture, choloenteric fistula, and an aberrantly placed stent. Bile duct brushings were performed on the high grade bile duct stricture (Figure 1).

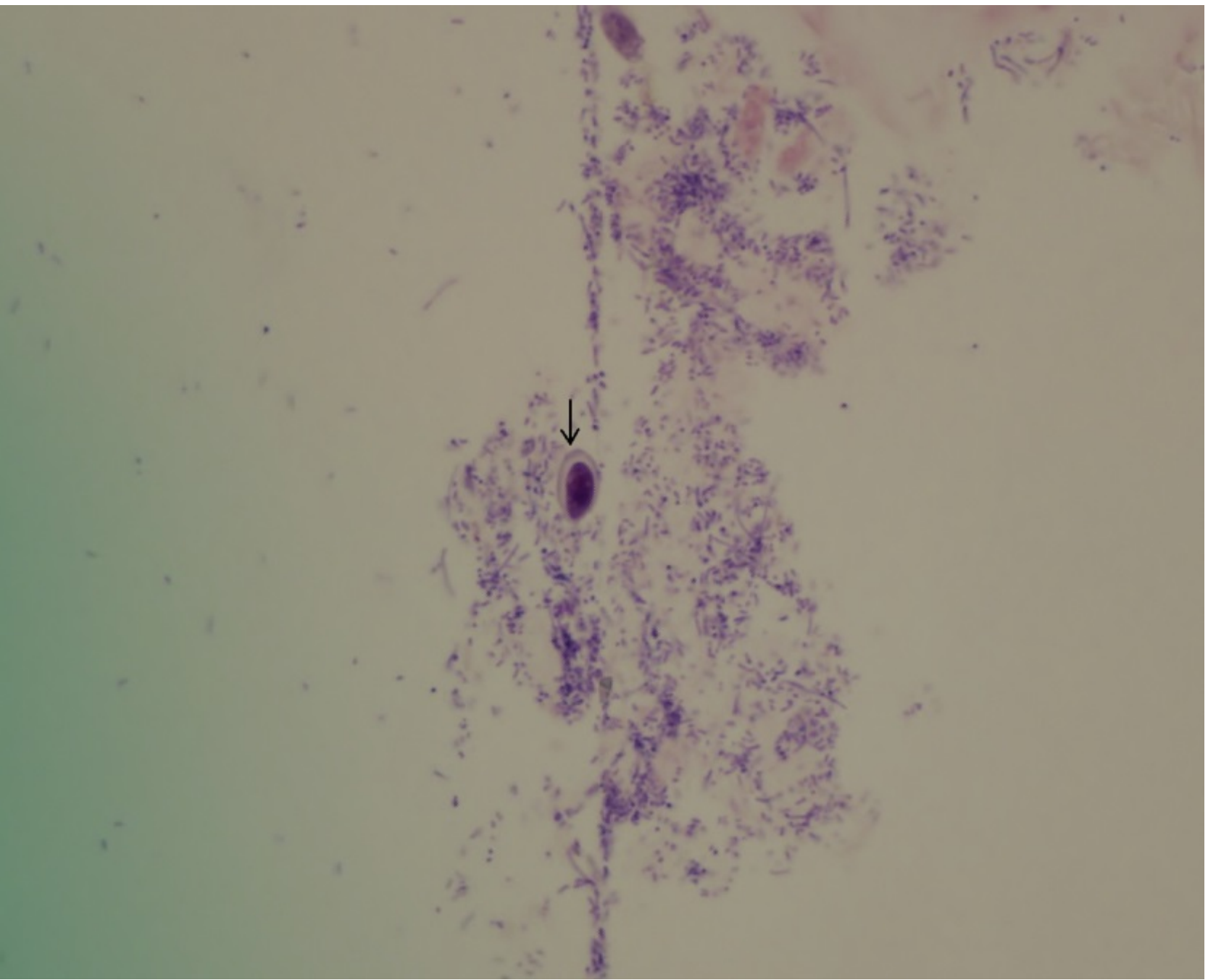

Figure 1: Bile duct brushings showed abundant bacteria and a parasitic egg with a shouldered operculum (arrow) and terminal knob, consistent with Clonorchis spp. 